\title{
Crystal structure of calcium iron zinc catena-disilicate, $\mathrm{Ca}\left(\mathrm{Fe}_{0.19} \mathrm{Zn}_{0.81}\right) \mathrm{Si}_{2} \mathbf{O}_{6}$
}

\author{
M. Heuer*.I, A. Huber ${ }^{\text {Il }}$ and G. J. Redhammer ${ }^{\mathrm{III}}$ \\ 1 Universität Leipzig, Institut für Mineralogie, Kristallographie und Materialwissenschaft. Scharnhorststr. 20, D-04275 Leipzig, Germany \\ " Ludwig-Maximilians-Universität München, Institut für Mineralogie. Petrologie und Geochemie, Theresienstr 40, D-80333 München, Germany \\ ${ }^{111}$ RWTH Aachen. Institut für Kristallographie, Jägerstr. 17/19, D-52056 Aachen, Germany
}

Received July 19. 2002, accepted and available on-line October 10, 2002; CSD-No. 409642

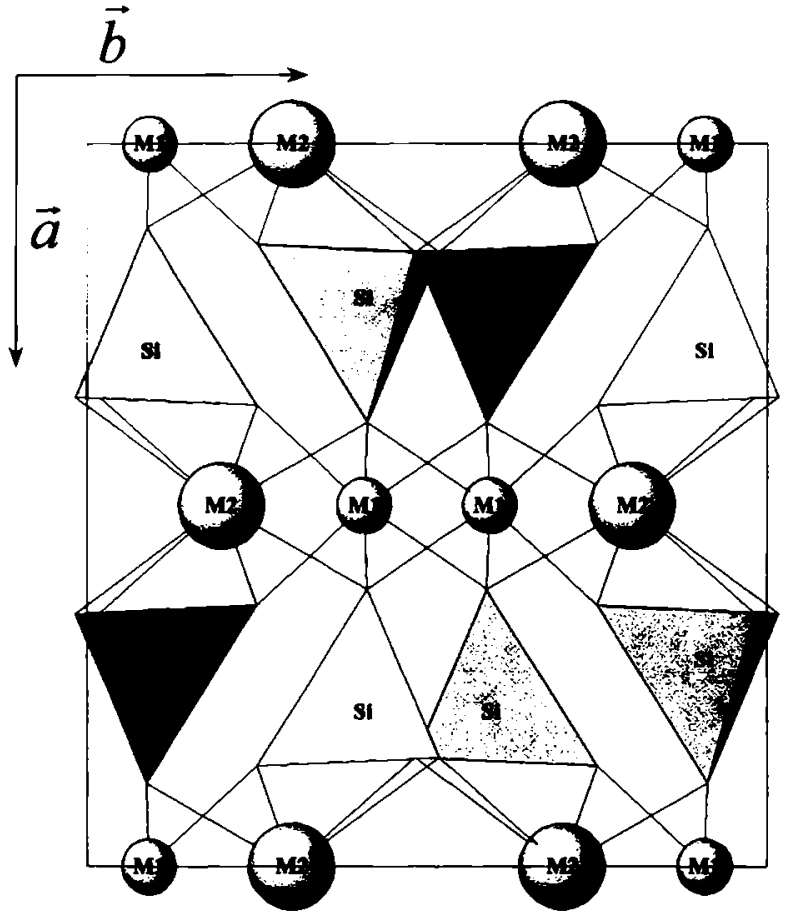

Abstract

$\mathrm{CaFe}_{0.19} \mathrm{O}_{6} \mathrm{Si}_{2} \mathrm{Zn}_{0.81}$, monoclinic, $C 12 / c 1$ (No. 15), $a=9.8093(7) \AA, b=8.9817(7) \AA, c=5.2527(4) \AA, \beta=105.66(1)^{\circ}$, $V=445.6 \AA^{3}, Z=4, R_{\mathrm{gt}}(F)=0.025, w R_{\mathrm{ref}}\left(F^{2}\right)=0.061, T=293 \mathrm{~K}$.

\section{Source of material}

Single crystals of $\mathrm{Ca}_{1.00(1)} \mathrm{Fe}_{0.21(2)} \mathrm{Zn}_{0.85(3)} \mathrm{Si}_{1.97(1)} \mathrm{O}_{6}$ were obtained under high pressure and high temperature conditions. Starting with a stoichiometric mixture of oxides (purity >
99.999\%) the synthesis was performed in a Piston-Cylinder apparatus over 3 days with a temperature of $1473 \mathrm{~K}$ and a pressure of $2.5 \mathrm{GPa}$. The chemical composition of the crystal was determined by electron microprobe (CAMECA SX50, $15 \mathrm{kV} / 15 \mathrm{nA}$, standards: wollastonite $\mathrm{CaSiO}_{3}$, hematite $\mathrm{Fe}_{2} \mathrm{O}_{3}$, and sphalerite $\mathrm{ZnS}$ ).

\section{Discussion}

The investigated material has a clinopyroxene structure [1] in which $\mathrm{Zn}^{2+}$ shares the M1 position with $\mathrm{Fe}^{2+}$. The M2-site is completely occupied by $\mathrm{Ca}^{2+}$. In the most structures zinc is tetrahedral coordinated $[2,3]$ and the octahedral coordination of zinc in pyroxenes is an exception. This is also expressed in the distortion of the $\mathrm{Zn}$-containing M2-site. Comparing to $\mathrm{CaFeSi}_{2} \mathrm{O}_{6}$ we find shorter $d(\mathrm{M} 1-02)(2.0733(9) \AA)$ and $d(\mathrm{M} 1-01)(2.0849(9) \AA)$ distances but no changes in the $\mathrm{M} 1-01$ length $(2.1595(9) \AA)$. The lattice parameters of the material were determined by powder diffraction.

Table 1. Data collection and handling.

\begin{tabular}{|c|c|}
\hline Crystal: & $\begin{array}{l}\text { light yellow fragment, } \\
\text { size } 0.16 \times 0.19 \times 0.290 \mathrm{~mm}\end{array}$ \\
\hline Wavelength: & Mo $K_{\alpha}$ radiation $(0.70932 \AA)$ \\
\hline$\mu: \quad$ & $69.7 \mathrm{~cm}^{-1}$ \\
\hline Diffractometer, scan mode: & Bruker AXS P4, $\omega$ \\
\hline $2 \theta_{\max }:$ & $80.02^{\circ}$ \\
\hline$N(h k l)_{\text {measured, }} N(h k l)_{\text {unique: }}$ & 1706,1389 \\
\hline Criterion for $I_{\mathrm{obs}}, N(h k l)_{\mathrm{gt}}$ : & $I_{\text {obs }}>2 \sigma\left(I_{\text {obs }}\right), 1299$ \\
\hline$N(\text { param })_{\text {refined: }}$ & 50 \\
\hline Program: & SHELXL-97 [4] \\
\hline
\end{tabular}

Table 2. Atomic coordinates and displacement parameters (in $\AA^{2}$ ).

\begin{tabular}{|c|c|c|c|c|c|c|c|c|c|c|c|}
\hline Atom & Site & Occ. & $x$ & $y$ & $z$ & $U_{11}$ & $U_{22}$ & $U_{33}$ & $U_{12}$ & $U_{13}$ & $U_{23}$ \\
\hline $\mathrm{Zn}(\mathbf{M} \mathbf{1})$ & $4 e$ & $0.810(1)$ & 0 & $0.90590(2)$ & $1 / 4$ & $0.0123(1)$ & $0.0119(1)$ & $0.0106(1)$ & 0 & $0.00289(7)$ & 0 \\
\hline $\mathrm{Fe}(\mathrm{M} 1 \mathrm{1})$ & $4 e$ & 0.190 & 0 & 0.90590 & $1 / 4$ & 0.0123 & 0.0119 & 0.0106 & 0 & 0.00289 & 0 \\
\hline $\mathrm{Ca}(\mathrm{M} 2)$ & $4 e$ & & 0 & $0.30017(4)$ & $1 / 4$ & $0.0156(1)$ & $0.0128(1)$ & $0.0120(1)$ & 0 & $0.0015(1)$ & 0 \\
\hline $\mathrm{Si}(\mathrm{T} 1)$ & $8 f$ & & $0.28672(4)$ & $0.09259(3)$ & $0.22966(7)$ & $0.0101(2)$ & $0.0104(2)$ & $0.0097(1)$ & $-0.00022(8)$ & $0.0030(1)$ & $-0.00025(8)$ \\
\hline$O(1)$ & $8 f$ & & $0.1169(1)$ & $0.08914(9)$ & $0.1455(2)$ & $0.0106(3)$ & $0.0134(3)$ & $0.0118(3)$ & $0.0005(2)$ & $0.0028(3)$ & $0.0003(2)$ \\
\hline$O(2)$ & $8 f$ & & $0.3607(1)$ & $0.2480(1)$ & $0.3218(2)$ & $0.0152(3)$ & $0.0118(3)$ & $0.0137(3)$ & $-0.0025(3)$ & $0.0037(3)$ & $-0.0006(3)$ \\
\hline
\end{tabular}

\footnotetext{
* Correspondence author (e-mail: heuer@rz.uni-leipzig.de)
} 
Acknowledgments. The authors thank Th. Fehr and $\mathrm{K}$. Bente for discussion and the Deutsche Forschungsgemeinschaft for financial support (Be 1088/11, Fe235/5).

\section{References}

1. Burnham, C. W.; Clark, J. R.; Papike, J. J.; Prewitt, C. T.: Proposed cyrstallographic nomenclature for clinopyroxene structures. $Z$. Kristallogr. 125 (1967) 109-119.

2. Yeh, C. Y.; Lu, Z. W.; Froyen, S.; Zunger, A.: Zinc-blende-wurtzite polytypism in semiconductors. Phys. Rev. B 46 (1992) 10086-10097.
3. Klaska, K. H.; Eck, J. C.; Pohl, D.: New investigation of willemite. Acta Crystallogr. B 24 (1978) 3324-3325.

4. Sheldrick, G. M.: SHELXL-97. A program for refining crystal structures. University of Göttingen, Germany 1997. 